\title{
INTELLIGENT WAYS FOR ENHANCING THE PROCESS OF PLACING, RETRIEVING, AND RECEIVING ORDERS FOR PRODUCTS AND SERVICES FROM A VIRTUAL SHOP
}

\author{
Olunlade B.A. ${ }^{1 凶}$, Efozia N. F. ${ }^{*}{ }^{2}$ (iD \\ 1. ${ }^{2}$ Prototype Engineering Development Institute (PEDI), NASENI, Ilesa, Osun State, Nigeria
}

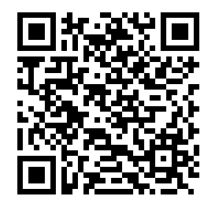

DOI: https://doi.org/10.29121/granthaalayah.v9.i2.2021.3237

Article Type: Research Article

Article Citation: Olunlade B.A., and Efozia N. F.. (2021). INTELLIGENT

WAYS FOR ENHANCING THE

PROCESS OF PLACING, RETRIEVING, AND RECEIVING ORDERS FOR PRODUCTS AND SERVICES FROM A VIRTUAL SHOP. International Journal of Research GRANTHAALAYAH, 9(2), 193-202. https://doi.org/10.29121/granthaa layah.v9.i2.2021.3237

Received Date: 22 January 2021

Accepted Date: 28 February 2021

Keywords:

Virtual Shop

Intelligent

Enhancing

Process

Orders

\section{ABSTRACT}

Doing of business has been made easier, better, and faster with the use of the Internet, this has led to the changes in the way people do business. There is now a rapid worldwide growth trend towards virtual stores also referred to as digital shops or stores or e-commerce. The paper discussed the ways to intelligently enhance the process of placing, receiving and retrieving orders on products and services from the virtual shops by clients.

\section{INTRODUCTION}

With the rapid growth in technology usage for conducting commercial transactions in business organisations over traditional methods of direct physical buying and selling from shops and stores, the internet is now the means most business organisation use to sell their products. This brings about the need for virtual shops which is on for a while now. It also formed the basis for the enhancement of the processes involved in virtual shop that would enable customer and prospective buyers of business organisations goods and services to place, as well as retrieve and receive orders needed to be intelligently done in order to boost ROI and customers' satisfaction.

The Internet being a global network of connections and also the world's fastest growing commercial market place, with its standard in business which is significant and accepted as a developed business standard by which clients and business persons do come together to carry out buying and selling process. This has led firms and businesses of today to incorporate the concept of e-commerce in most levels of their operations, to the point that some traditional companies without Internet facilities now integrated it into their businesses. And so, many physical

(C) 2021 The Author(s). This is an open access article distributed under the terms of the Creative Commons Attribution License, which permits unrestricted use, distribution, and reproduction in any medium, provided the original author and source are credited. 
Intelligent Ways for Enhancing the Process of Placing, Retrieving, And Receiving Orders for Products and Services from A Virtual Shop

retail stores have expanded their marketing prospect through the Internet, by having both a virtual and a physical store, this guarantees them the best of both worlds.

To boost the digital market business of organisations, high-volume websites, such as Yahoo!, Amazon.com and eBay, now offer hosting services for online stores and to retailers for their products and services. These stores are presented as part of an integrated navigation framework and the collections of online stores are sometimes known as virtual shopping malls or online marketplaces (UKEssays, 2018).

E-commerce and online (virtual or digital store) shop has numerous benefits, for this reason many sales persons have to know how to sell their brand's products and services on the internet in such a way that buyers who these days do a lot of research on various brands before buying directly in the virtual shops via their devices, will need to be attracted and then be loyal to a particular brand. It implies the sales, (that is digital sales) personnel must be intelligent enough to enhance their marketing skills especially as it pertains to the process of how buyers should place orders, retrieve, receive and pay for their orders within stipulated time frame and at minimum cost.

The digital sales personnel could be intelligent agent software placed in the website hosting a virtual shop, with all the features of intelligence that would be enhancing the placing, receiving and retrieving of orders by customers.

\section{RELATED LITERATURES}

According to Wikipedia September, 2020, Online shopping is a form of electronic commerce which allows consumers to directly buy goods or services from a seller over the Internet using a web browser. That is consumers find a product of interest by visiting the website of the retailer directly or by searching among alternative vendors using a shopping search engine, which displays the same product's availability and pricing at different e-retailers. Presently, customers can shop online using a range of different computers and devices, including desktop computers, laptops, tablet computers and smartphones.

Online shop is presently evoking the physical analogy of buying products or services at a regular "bricks-andmortar" retailer or shopping center. This process is called what is referred to as business-to-consumer (B2C) online shopping. Next, if an online store is set up to enable businesses to buy from other businesses, the process is called business-to-business (B2B) online shopping. With a typical online store customer are able to browse the firm's range of products and services, view photos or images of the products, along with information about the product specifications, features and prices.

Usually, Online stores enable shoppers to use "search" features to find specific models, brands or items. The online customers must have access to the Internet and a valid method of payment in order to complete a transaction, such as a credit card, an Interactive enabled debit card, or a service such as PayPal. As for physical products such as paperback books or clothes, the retailer ships the products to the customer while for digital products, such as digital audio files of songs or software, the retailer sends the file to the customer over the Internet.

When compared with conventional retail shopping, the information environment of virtual shopping is enhanced by providing additional product information such as comparative products and services, as well as various alternatives and attributes of each alternative, and so on. Two major dimensions of information load are complexity and novelty. Complexity refers to the number of different elements or features of a site, often the result of increased information diversity. Novelty involves the unexpected, suppressed, new, or unfamiliar aspects of the site. The novelty dimension may keep consumers exploring a shopping site, whereas the complexity dimension may induce impulse purchases. Of note online shopping is seen as the customers shopping behaviour to shop online.

Online retail also referred to as virtual store or shop dates as far back as the 1990s if not before such as in the 1980s where Tesco and Asda dabbled with home shopping services via computer in the mid-1980s but with the invention of the world wide web (WWW) by Tim Berners-Lee then comes the widespread consumer use of the internet becoming a possibility. From 1995 came Amazon which was launched as an online book, next was ebay, Sainsbury, Blackwells, Toys, and so on, there were at that time 16million users on the internet, but as at 2019 there has being over a trillion users of the internet as well as buying and selling online being done, due to the exponential growth of the internet usage by persons worldwide (Finona, 2019).

The electronic commerce, commonly known as E-commerce or e-commerce, which has to do with trading in products or services conducted via computer networks such as the Internet, draws on technologies such as mobile commerce, electronic funds transfer, supply chain management, Internet marketing, online transaction processing, electronic data interchange (EDI), inventory management systems, and automated data collection systems. Presently 
most electronic commerce uses the World Wide Web at least at one point in its transaction's life-cycle, although it may encompass a wider range of technologies such as e-mail, mobile devices, social media, and telephones.

Also, E-Business is the term used to describe the information systems and applications that support and drive business processes, most often using web technologies. It allows companies to link their internal and external processes more efficiently and effectively, and work more closely with suppliers and partners to better satisfy the needs and expectations of their customers, leading to improvements in overall business performance. While a website is one of the most common implementations, E-Business is much more than just a web presence. There is a vast array of internet technologies all designed to help businesses work smarter not harder. E-commerce refers to online transactions - buying and selling of goods and/or services over the Internet. It covers online transactions, but also extends to all Internet based interactions with business partners, suppliers and customers such as: selling direct to consumers, manufacturers and suppliers; monitoring and exchanging information; auctioning surplus inventory; and collaborative product design. These online interactions are aimed at improving or transforming business processes and efficiency (Saimunur, 2014).

Furthermore, Virtual shopping is the process of buying goods and services from merchants who sell on the Internet and people can purchase just about anything from companies that provide their products online. Online shopping is a form of Electronic Commerce. E-commerce or Electronic commerce, is a subset of E-Business (a company that does all or most of its transactions through the Internet), is the purchasing, selling, and exchanging of goods and services over computer networks (such as the Internet) through which transactions or terms of sale are performed electronically. Increase in sales. Increase in customers, ability to be open 24/7, instant processing of transactions. Increased business reach. Use electronic payment refers to paperless monetary transactions. These business transactions occur either as business-to-business (B2B), business- to-consumer (B2C), consumer-toconsumer (C2C) or consumer-to-business (C2B). The terms e-commerce and e-business are often used interchangeably. The term E- Tail (electronic retailing) is also sometimes used in reference to transactional processes for E-Shopping or Online Shopping. E-Shopping or Online Shopping E-Shopping is the browsing and purchase of goods using computer (Internet) or Television catalogue; also called Home Shopping. Online Shopping is a form of e-commerce which allows customers to directly buy goods form seller over the Internet (Kusum, 2016).

Also, every 50 years or so, retailing undergoes this kind of disruption. A century and a half ago, the growth of big cities and the rise of railroad networks made possible the modern department store. Mass-produced automobiles came along 50 years later, and soon shopping malls lined with specialty retailers were dotting the newly forming suburbs and challenging the city-based department stores. The 1960s and 1970s saw the spread of discount chains such as Walmart, Kmart, and the like and, soon after, big-box "category killers" such as Circuit City and Home Depot, all of them undermining or transforming the old-style mall. Each wave of change doesn't eliminate what came before it, but it reshapes the landscape and redefines consumer expectations, often beyond recognition. Retailers relying on earlier formats either adapt or die out as the new ones pull volume from their stores and make the remaining volume less profitable.

Like most disruptions, digital retail technology got off to a shaky start. A bevy of internet-based retailers in the 1990s-Amazon.com, Pets.com, and pretty much everythingelse.com-embraced what they called online shopping or electronic commerce. These fledgling companies ran wild until a combination of ill-conceived strategies, speculative gambles, and a slowing economy burst the dot-com bubble. The ensuing collapse wiped out half of all e-commerce retailers and provoked an abrupt shift from irrational exuberance to economic reality.

Today, however, that economic reality is well established. The research firm Forrester estimates that ecommerce is now approaching $\$ 200$ billion in revenue in the United States alone and accounts for $9 \%$ of total retail sales, up from $5 \%$ five years ago. The corresponding figure is about $10 \%$ in the United Kingdom, $3 \%$ in Asia-Pacific, and $2 \%$ in Latin America. Globally, digital retailing is probably headed toward $15 \%$ to $20 \%$ of total sales, though the proportion will vary significantly by sector. Moreover, much digital retailing is now highly profitable. Amazon's fiveyear average return on investment, for example, is $17 \%$, whereas traditional discount and department stores average $6.5 \%$. What we are seeing today is only the beginning. Soon it will be hard even to define e-commerce, let alone measure it (Darrell, 2011).

Enhancing intelligently the placing, receiving and retrieving process of a virtual shop implies a smarter, quicker, more responsive process or ways of placing, receiving and retrieving orders. This process would be put in place by the merchant in its website that host its virtual shop such that clients would be able to make orders with ease and get response as par receiving and retrieving their orders as at when due with little or no constraints. 
Intelligent Ways for Enhancing the Process of Placing, Retrieving, And Receiving Orders for Products and Services from A Virtual Shop

Common characteristics of all these types of virtual operations are:

- Use of information and communications technology to allow dispersed operations

- Reduced importance (even collapse) of time and space

- New kinds of networking organizational structures, often dynamic in nature

- Changing ways of interfacing with customers and markets

- New ways of working for employees and associates (such as business partners, suppliers, customers and so on).

\subsection{ADVANTAGES OF VIRTUAL SHOP (ONLINE)}

The advantages of digital retailing are increasing as innovations flood the market. For instance, Amazon has already earned valuable patents on keystone innovations such as 1-Click checkout and an online system that allows consumers to exchange unwanted gifts even before receiving them. Digital retailers drive innovation by spending heavily on recruiting, wages, and bonuses to attract and retain top technical talent. They were also among the first to utilize cloud computing (which dramatically lowers entry and operating costs) and to enhance marketing efficiency through social networks and online advertising (Darrell, 2011).

The use of the internet for commercial transaction has now taken over the traditional method used by business organisation. So, businesses now place their goods and services' online, thereby having what is called virtual (online) shop or store. As the internet has no constraint as par limit to what websites can display, buyers with analytical mindset have the opportunity of getting the best out of the lots of same or similar brands displayed on the internet after a good search has been done. The following are the benefits of virtual (online) shop (Money-Matters, 2020);

- Convenience of online shopping

- No pressure shopping

- It saves time

- Comparison

- Availability of Virtual shop 365days, $24 / 7$

- Online tracking

- It saves money

\subsection{LIMITATIONS OF VIRTUAL (ONLINE) SHOPS}

Despite its benefits, virtual store/shop does have some limitations, such as;

- Delay in delivery

- Lack of significant discounts

- Lack of touch and feel of merchandise such as clothes cannot be tried on for sizing and fitness on customer

- Lack of interactivity such price negotiation that can be done in physical stores

- Lack of shopping experience such as smart sales attendant, scents, fun atmosphere, etc

- Lack of close examination of the product to be bought

- Fraud concerns

- Privacy of personal information is a significant issue for some consumers. Many consumers wish to avoid spam and telemarketing which could result from supplying contact information to an online merchant.

\section{METHODOLOGY}

Incorporating intelligent agents in virtual shop website is a valuable way to achieve the intelligent enhancing of the process of placing, receiving and retrieving of orders for products and services. This would be achievable as the characteristics of agent technology would assist in ensuring goods and services are placed in the right order for ease of access by clients and receiving and retrieving of such orders. The features of agent technology as par being able to autonomously act proactively, adaptively and reactively by itself or through communication with other agents intelligently is to persistently achieve the task assigned to it on behalf of its users or other agents. 
With such agents in the virtual shop clients can be directed appropriately and their questions and needs met accurately so decisions would be made as par placing, receiving and retrieving orders with ease and confidently. So clients would want to visit such shops website regularly as well as introduce other clients/customers to do same because of their positive experience with such intelligent process of placing, receiving and retrieving orders in the virtual shop of such brands.

Other key processes are using barcoding and radio frequency controls, which offer standard ways of reading and recording data, but the physical materials handling logistics and ways of doing things in each warehouse are somewhat unique to each business. This is driven by factors including magnitude of the warehouse operation, storage capacity, temperature, order profiles, legislative requirements, company culture, and volume of goods moving through the facility. key processes and how they are handled is as stated below (Mal Walker,2018):

\section{Receiving}

The act of handling products into a warehouse and onto a system.Receipts may be for single products, objects, litres, cartons, packets, crates, kilograms or full pallets. Items maybe large such as pallets or as small as a split pin. The best way to receive products is via an Advance Shipping Notice (ASN) from a supplier. With this information on system, operators can scan consignment barcodes to bring up the ASN. If the delivery matches the ASN, then goods can be system-received. But at this point they are still at staging, albeit ready for put-away. Some systems allow for goods to be received into inventory at this point, whereas others require the goods to be delivered to a specific stock location before inventory is updated. This depends entirely on the customer requirements and how the system is set up. Note, Organise ASN on your system for automatic receiving and put-away, ideally, use radio frequency (RF) equipment for scanning and updating your management systems.

\section{Put-Away}

A good system will prompt put-away staff with a note indicating that stock is in staging waiting to be transported to a storage location. The process commences when operators accept the put-away task from the Enterprise Resource Program (ERP) or Warehouse Management System (WMS), and then scanning the relevant barcode of goods to be put away. If there is no barcode, then a manual entry can confirm that the goods have been identified. At this point the system will be directing the put-away staff to deliver goods to the relevant storage location. Once at the location, the operator will either scan the relevant stock location barcode, or manually confirm that the correct location has been found, then place the goods into the slot before confirming that the put-away process is complete. Note, make use of a system that can direct put-away to vacant slots according to demand of the goods.

\section{Picking}

There are two main types of picking.

Primary: This is the first picking of goods. In some cases, the first picking is delivered directly to a staging area or packing bench for finalisation, consigning and dispatching, thus the first picking becomes the last picking.

Secondary: This is a second picking process. Some primary picks are subject to a second picking process, particularly where picked goods must be allocated to clustered orders (bunch of orders), or discrete orders (single orders) via a sortation process or system. With the boom in online sales across many industries, far more companies are conducting secondary picking processes than ever before.

Once orders are received, it is common for orders to be released 'real-time' or in 'waves'. Real-time orders are downloaded as they are received. Orders accumulated for specific picking times and transport routes are called 'waves.

Waves can be released at the discretion of the DC manager according to criteria that they determine. As alluded to above, picking may be discrete, that is, one order at a time, clustered, i.e., multiple orders at a time, or batched, i.e., picking all the goods at once to sort to specific customer orders.

Often, companies may use all three types of picking. With increasing online orders, companies are increasingly installing picking apparatus such as put walls, put-to-light systems, goods-to-person systems and cross-belt sortation systems, to cope with the larger volume of small orders.

What about accuracy of picking? This is one of the most common questions asked by warehouse managers. Should you scan the product or location, or both during picking? Note, the unrelenting technology improvement and complexity of modern-day business dictates that companies invest in appropriate ERP and WMS systems to remain 
Intelligent Ways for Enhancing the Process of Placing, Retrieving, And Receiving Orders for Products and Services from A Virtual Shop

competitive. Picking uses a large amount of resources, and can reflect around $60 \%$ or more of warehouse staff. Smart picking systems and WMS are a must for increasingly complex businesses.

This depends largely on the degree of accuracy required. If both are scanned accuracy increases, but picking velocity will be lower compared to simply scanning the location. Where voice systems are used, no scanning will be used, but check digits at the location serve to ensure the operator is at the correct location. Voice picking obviates the need to scan at all, but with a touch of risk. The risk lies in the operator achieving the right count, upon picking, without making a mistake.

While companies worry about the accuracy issue, evidence suggests that voice picking and/or scanning the location only, gives a surprisingly high level of accuracy, without impeding picking velocity. For 'accuracy intensive' warehouses, accuracy can be enhanced by a statistical example of QA checks, normally around 10 to $20 \%$ of orders.

\section{Packing}

There are scores of ways that goods are packed within distribution centres. Rather than delve into the specific details of packing processes, it's sufficed to follow five rules for successful packing:

1) Goods picked must be traceable in terms of location from which they are picked, plus relevant 'use-by' dates and/or 'batch' dates and codes.

2) Accuracy and QA checks must be built into the process.

3) Goods picking from different zones within the warehouse must be easily 'combined' and system-managed to ensure order completeness.

4) Goods must be packed according to their size, quantity, temperature, toxicity, value, fragility, hygiene and legislative requirements.

5) Consignments must always be system-traceable to documents and/or invoice numbers for future traceability.

Note Packing is an extension of the picking process and must be system-managed and treated with care to ensure that orders are complete, and accurate.

\section{Dispatching}

The successful art of dispatch lies in the operation's ability to have goods ready for departure, just in time for carriers to load their trucks. The DC manager must therefore balance and forecast packing and dispatching according to carrier pick-up times. Goods that are ready too early, for example, will clutter staging areas, while dispatches that are late, will delay loading and potentially cause late deliveries.

As indicated earlier, many firms resort to using their systems to release orders, for picking and packing in waves, aligned to specific delivery routes or carrier types. Note, Avoid jambs and late deliveries by scheduling picking waves to align with carrier picking up times.

\section{Returns}

This is something most companies wish will just disappear! However, returns are an intricate part of most businesses, and alas, the volume of returns is growing for many organisations - mainly due to the e-commerce revolution. Alarmingly, much of returns for many firms are for just one item at a time.

The complexity around handling returns mandates the following rules:

1) When customers return goods, they should seek, and be given Return Management Authorisation, which outlines what is being returned and why.

2) All returns must be traceable, to their order, document and invoice.

3) Companies must have a pre-determined returns process that delineates what is to be done with the goods once received back into the warehouse, e.g., return to stock, repair, destroy, discard, recycle, return to manufacturer, etc.

4) All credits must be system-recorded together with reasons why the goods are returned.

5) Inventory must be updated where goods are returned to stock, or held for further action.

Note, Returns is a complex part of any business. A defined process must be in place that accurately and reliably records the whole transaction and credit process. 


\section{Value-Adding}

This is the part of the business where products are produced, kitted, assembled, relabelled, modified, 'burnt-in', or subject to some other value adding process. The value adding part is about performing work on the product to make it 'ready for sale'.

This process of value-adding can be complex, particularly when many different items are combined to form a new product. Complexity around handling value-adding processes and the changing nature of component products in and out of shelf locations can be daunting. Over the years, systems have evolved to assist, yet there are many companies that find recording of value adding components may be incompatible with how the logistics system or conventional ERP or WMS have been set up. Note, review your value-adding processes and make sure that your system can handle the requisite activities and transactions.

In conclusion, from the above, you will realise that modern distribution centre supply chains are a complex mass of processes, activities and transactions. All of which must be individually crafted by humans to make your warehouse operate effectively.

The days of using a pad and pencil or even a spreadsheet to manage warehouse functions do seems very long ago, yet the unrelenting technology improvement and complexity of modern-day business dictates that companies invest in appropriate ERP and WMS systems to remain competitive. Equally important is that they are correctly configured to the 'different' aspects of your business.

Overall, for online retailers to take over the market and get established, it is imperative that they develop strategies for improving customers overall experience online. There is need for retailers to exceed the customers' expectations of just an automated buying and selling process. Some major online retailers in developed countries have introduced additional online features such as virtual testing of products like clothes and accessories. Customers upload their pictures dresses are tested on the picture online. This can also be done for accessories like sunglasses and prescription glasses. With such an invention, the need to visit physical stores is greatly reduced and customers will begin to enjoy seamless online shopping experience (Gabriel, et al, 2016).

\section{SYSTEM DESIGN AND IMPLEMENTATION}

\subsection{STRATEGIES FOR CREATING AN INTELLIGENTLY ENHANCED ONLINE STORE (VIRTUAL SHOP) SUCCESSFULLY}

Sellers with their own online stores play a different game. They have complete control over their customers' experiences. Whether it's rearranging product placement or highlighting a store sale, merchants can use their website to directly connect with their customers and encourage purchases (OksanaPreda, 2020).

- Engaging web Design

- An awesome "about us" page

- Partner with other brands - for the purpose of reputation and gaining customers/clients' trust

- Offer of excellent online support

- Provide popular payment options

- Advertise on social media

- A useful, SEO-driven blog (Selling Enterprise Online)

- Build buyer trust with product reviews

- Make your site SEO friendly

- Ensure Your Store is Mobile-Responsive

- Track Analytics and Iterate

- Offer Free Shipping

- Build Your Outreach List

- Use Ready-to-Go Storefront Tools

- Keep an Eye on the Competition

- Use High-Res Photos

- Offer Incentives

- Take Advantage of Email Marketing 
Intelligent Ways for Enhancing the Process of Placing, Retrieving, And Receiving Orders for Products and Services from A Virtual Shop

- Offer Generous Refund and Money-Back Guarantee Policies

- Ensure customers privacy information are intelligently protected from malicious hackers.

For ease in intelligently enhancing the process of placing, receiving and retrieving items in the digital (virtual or online) shop, the following is expected;

1) Intelligently creates departments within it such as shoes department, cosmetics, clothes, gold, silver, and so on departments. As well as that of services do same.

2) Make the display of goods and services to be attractive with intelligent display methods that sets a tone and expectation. With this you sell not just your products but your intelligent experience skills. With an intelligent merchandize display a message is sent to the would be buyer or client.

3) Use planogram a type of diagram to detail placement of items in the virtual shop.

4) Ensure the atmosphere in the virtual shop is pleasant with lightning, music in the website, so the color combination is vital.

5) Intelligently ensure ease of accessibility of the goods and services as well as good sigh directions to help customers navigate the shop online.

6) Intelligently ensure customer and client receive their goods and services as at when due. If refund is needed do it promptly and friendly.

7) Ensure fraud is prevented as par cash handling, transfer credit cards, debit cards, and so on. Have internal control merchanism.

8) Handling of ordered goods and services to ensure customers and buyers receiving their requested goods or items in good condition and it meets their expected demand and quality.

9) Have inventory control and tracking system to ensure the right customer gets its request delivered rightly. Tracks customers' purchase in order to create customized promotions.

10) Ensure an intelligent data management system with the use of technology such as barcoding and use of a customer relationship management (CRM) platform. This would guide targeted customers towards sales and offers build customer loyalty and improve customer service. The technology can also be used to root out bottlenecks and discrepancies thereby increasing efficiency and timeliness.

In summary, Online stores cum virtual shop give merchants complete autonomy over the customers' experiences. Instead of following a marketplace's policies, a seller can set up their own online shop by their terms to shape their buyers' product interactions as well as using intelligent agents to intelligently enhance the virtual store or shop website interaction.

Merchants with this freedom as an online store owner can encourage more conversions if they know how to craft each element of their shop. By following the strategies outlined in this guide, merchants can become more aware of how customers perceive every store element and apply that knowledge to create their shop. Curating an online store to align with key buyers' wants and motivations gives sellers an edge over less concerned competitors.

Also, problems that undermine consumers' confidence in online shopping includes fraud and security concerns. These include identity theft, phishing, denial of service attacks, and so on. The perpetrators get hold of consumer's credit card information and use it to commit fraud. To combat this, most online businesses adopt encryption on their websites as well as other security measures to prevent fraudsters from getting hold of customers information. The use of Paypal accounts is also useful in securing against fraud on the Internet (UKEssays, 2018).

\section{FINDINGS, RESULTS AND DISCUSSIONS}

The ease and convenience of shopping online will always lure more consumers to it. However, consumers must be alert and aware of the risks involved and take extra care when shopping online. Due to the openness and competitiveness of the online market or virtual shop, most business will always strive to maintain the highest standard of security as well as a user centred website to boost their business.

As observed, shopping online or digitally works better for elderly persons and persons with very busy work schedules, the virtual shops should have personal shopping bags on their websites that enables buyers or clients to store their selected products and services to be purchased later. These clients purchase or make payments via their 
credit, debit cards or with their internet banking facilities. For these reason intelligent security features like CAPATCHA is required to verify payment by authenticating buyers as well as secure their pass-code to their credit or debit card or internet banking credentials from malicious hackers, so that buyers and sellers are safe in getting value for money spent and as well return of investment (ROI).

Also, selling directly online (virtually or digitally) increases the manufacturers and sellers reach as their profit is not tied to only physical visit to their shops, as virtual shops enable them to sell across cities, state, countries and continents. The customer, also have variety of brands to choose from in digital or virtual shop globally.

\section{CONCLUSION AND RECOMMENDATION}

As it evolves, digital retailing or virtual shop and sometimes termed online shop as well as virtual market are quickly morphing into something so different that it requires a new name: omnichannel retailing. The name reflects the fact that retailers will be able to interact with customers through countless channels-websites, physical stores, kiosks, direct mail and catalogs, call centers, social media, mobile devices, gaming consoles, televisions, networked appliances, home services, and more. Unless conventional merchants adopt an entirely new perspective-one that allows them to integrate disparate channels into a single seamless omnichannel experience-they are likely to be swept away.

Therefore, the enhancing of the process of placing, retrieving and receiving orders for products and services intelligently becomes more vital for sellers and buyers alike.

\section{SOURCES OF FUNDING}

This research received no specific grant from any funding agency in the public, commercial, or not-for-profit sectors.

\section{CONFLICT OF INTEREST}

The author have declared that no competing interests exist.

\section{ACKNOWLEDGMENT}

None.

\section{REFERENCES}

[1] Darrell K. Rigby (2011) "The Future of Shopping", Harvard Business Review, December 2011 issue, hbr.org/dec-2011-issue/The-future-of-shopping.htm

[2] Finona Ellis-Chadwrick (2019) "History of Online Retail” Article online on 30th August, 2019, History of online retail-openLearn-open university.htm

[3] Gabriel J. M. O.*, T. D. Ogbuigwe and L. U. Ahiauzu (2016) "Online Shopping Systems in Nigeria: Evolution,Trend and Prospects" Asian Research Journal of Arts \& Social Sciences 1(4): 1-7, 2016, Article no.ARJASS.29170 SCIENCEDOMAIN international www.sciencedomain.org- 11032-ArticleText-20248-1-1020181108-pdf

[4] Kusum Sankhala (2016) "Online Shopping System", Published in Technology, slideshare.com/onlineshopping-system.htm

[5] Mal Walker (2018) “Spotlight on: 7 Key Warehouse Processes” This article, written on Jul 25, 2018, Manager at Logistics Bureau, was first published in the January/February 2018 issue of MHD Supply Chain Solutions. https://www.logisticsbureau.com

[6] Money Matters (2020) "Advantages and Disadvantages of Online Shopping", written by Money Matters All Management Articles https://accountlearning.com

[7] OksanaPreda (2020) "20 Killer Tips for Creating a Successful online StoreSellbrite A Godaddy Brand" https://www.sellbrite.com/blog/...htm 
Intelligent Ways for Enhancing the Process of Placing, Retrieving, And Receiving Orders for Products and Services from A Virtual Shop

[8] Saimunur Rahman (2014) "Introduction to E-Commerce Technology in Business" Munich, GRIN Verlag, https://www.grin.com/document/280494

[9] UKEssays (2018) "The Online Virtual Shopping Marketing Essay" November 2018 Retrieved from https://www.ukessays.com/essays/marketing/the-online-virtual-shopping-marketing-essay.php?vref=1. 